\title{
LONG-TERM TRENDS AND CHANGES IN NUMBERS AND DISTRIBUTION OF SOME WINTERING WATERFOWL SPECIES ALONG THE SWEDISH BALTIC COAST
}

\author{
Leif NILSSON
}

Department of Animal Ecology, Ecology Building, S-223 62 Lund, Sweden. E-mail: leif.nilsson@zooekol.lu.se

\begin{abstract}
Regular counts of wintering waterfowl have been undertaken as a part of the International Waterfowl Census (IWC) and the National Swedish Environmental Monitoring Program since 1964. After the first years, a network of annually surveyed sites was established for the calculation of annual indices. Country-wide surveys (also including aerial counts) were undertaken 1971-1974, 1987-1989, 1992-1993 (partial) and 2004. During the survey period, increasing trends were found in Mallard (Anas platyrhynchos), Tufted Duck (Aythya fuligula), Pochard (Aythya ferina), Goldeneye (Bucephala clangula), Red-breasted Merganser (Mergus serrator), Mute Swan (Cygnus olor) and Cormorant (Phalacrocorax carbo). Some of these trends reflect genuine population changes; others are related to changing winter conditions, e.g. the establishment of a new wintering tradition for Wigeon (Anas penelope). Tufted Duck and Goldeneye decreased in the south and increased in the northern part of the coast. Mallard, on the other hand, increased in some coastal sites but not in others, but this species is also common inland.
\end{abstract}

Key words: trends, numbers, distribution, waterfowl, Sweden

\section{INTRODUCTION}

Regular counts of wintering waterbirds started in Scania, the southernmost province of Sweden, in the sixties as part of a study of the non-breeding ecology of diving ducks (Nilsson 1970). A total count of the entire province was organised in January 1964. In January 1967 the local counts in Scania were included in the network of coastal and inland sites forming the Swedish contribution to the International Waterfowl Census (IWC). After the first years, when one important aim was to study distribution patterns etc., and more or less country-wide surveys were organised, a network of annually surveyed sites was established for the calculation of annual indices (Nilsson 1975, 1991). Country-wide surveys (also including aerial counts) were undertaken in 1971-1974, 1987-1989, 1992-1993 (partial) and 2004. The counts are since several years included in the National Environmental Monitoring Program of Sweden. As the theme of this conference is long-term site-based studies in the Baltic area I have chosen to analyse the changes in numbers and distribution of three important wintering waterfowl species, the Mallard (Anas platyrhynchos), Tufted Duck (Aythya fuligula) and Goldeneye (Bucephala clangula) based on counts in a subset of sites regularly surveyed in the Baltic coastal area of Sweden. I will also give some general informa- tion on other species for comparison and some background information from the country-wide surveys in 1971-1974 and 2004, respectively. A more full analysis of the Swedish Midwinter Counts since the start in 1971 is in progress (L. Nilsson, in prep.). Updated information from the project will also be found on the homepage: www.biol.lu.se/zooekologi/waterfowl/ index.htm.

\section{Material AND MEthods}

In connection with the organisation of the Midwinter Counts in Sweden, the entire Swedish coast was divided into counting units with natural borders easily identifiable in the field. These smaller units are grouped into larger sites with similar habitats. Inland, larger lakes and long rivers are divided into counting units in a similar way.

During the first years of midwinter counts, the aim was to get as high coverage as possible. Later, a standardised net of larger sites (consisting of a number of counting units) in coastal and inland areas was established to get data for the calculation of annual indices for the most important species. Data from more temporarily covered sites were also included in the database. In addition to the index sample, country-wide surveys were undertaken in 1971-1974, 1987-1989, 1992-1993 (partial) and 2004. 
Normally counts were undertaken from the ground, the same counters being employed for a number of years. Counts were mainly undertaken on the established international counting dates in mid-January, except in bad weather conditions. During the country-wide surveys, aerial surveys were undertaken in coastal areas. Counting methods are presented in more detail in Nilsson (1975, 1976, 1991).

Annual population indices were calculated from the counts by pair-wise comparison of the counts from sites covered in two consecutive years. The primary indices so obtained were then recalculated in relation to the selected base year, in which the index was set to 100 . This set of indices was later recalculated again to give indices with a mean of 100 for the entire index series. For further discussion of index calculations see Nilsson (1975, 1976, 1991).

In the present contribution I concentrate on nine larger areas distributed along the Baltic coast of Sweden, which have been covered completely for most years of midwinter counts (Fig. 1).

\section{Results}

The country-wide surveys in January 2004 differed markedly from the corresponding survey in 1971-1974 (Tables 1,2). Most species studied increased both in the areas of open coast and in the archipelagos. The

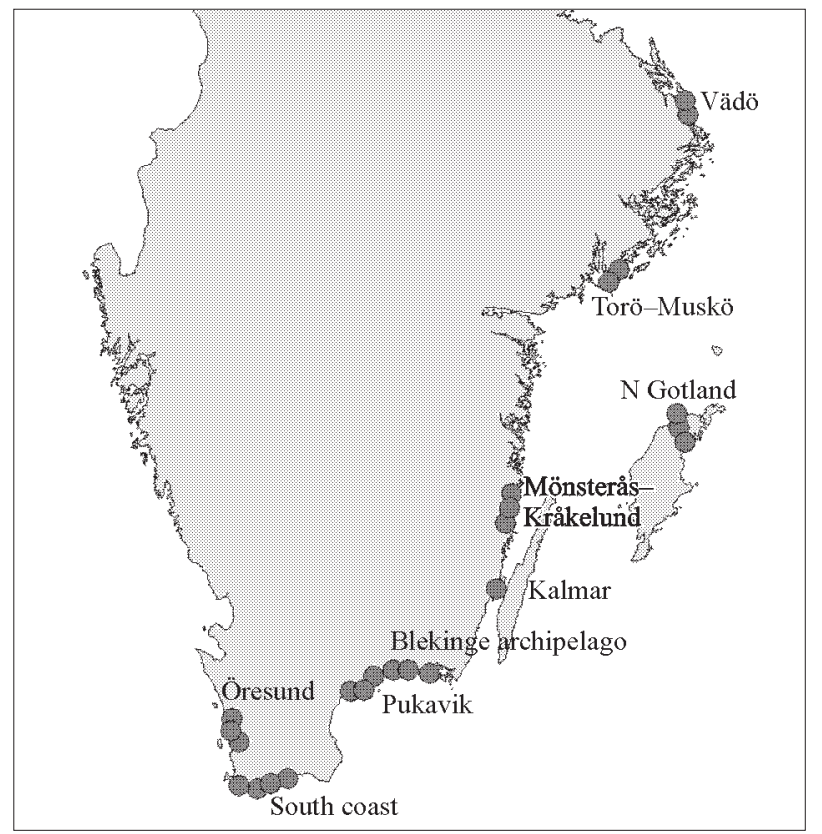

Figure 1. Map of south Sweden showing the geographical position of the sites included in the present analysis. increases were in some cases very marked, i.e. for the open coasts in Mallard, Wigeon, Tufted Duck, Goldeneye, Common Eider (Somateria mollissima), Goosander (Mergus merganser), Mute Swan and Cormorant, whereas the overall increase for Coot (Fulica atra) between the two censuses was only moderate. In Coot, national indices show a marked decrease after a cold winter in 1979 , followed by low indices and a later increase up to normal population levels. High counts in Wigeon in the last country-wide survey reflect a newly established wintering tradition in southernmost Sweden in recent years. In the archipelagos, all five species indicated in Table 2 increased, marked increases being found in Tufted Duck, Pochard and Mute Swan. The increase shown for Common Eider is mainly representative for the Kattegatt coast and not the Baltic proper, where the species still is quite sparse during midwinter at the Swedish coast.

The annual midwinter indices showed increasing trends over the study period for the following species: Mallard, Tufted Duck, Pochard, Goldeneye, Red-breasted Merganser, Mute Swan and Cormorant. Of these species, Redbreasted Merganser was not included in Tables 1 and 2

Table 1. Numbers counted of some species at country-wide surveys of the coast from northern Halland - northern Kalmarsund, including Öland and Gotland.

\begin{tabular}{lcr}
\hline Species & $1971-1974$ & \multicolumn{1}{c}{2004} \\
\hline Anas platyrhynchos & 28,000 & 73,400 \\
Anas penelope & 40 & 5,550 \\
Aythya fuligula & 52,500 & 149,000 \\
Bucephala clangula & 17,300 & 32,000 \\
Somateria mollissima & 3,200 & 9,700 \\
Mergus merganser & 3,600 & 8,400 \\
Cygnus olor & 5,900 & 20,700 \\
Fulica atra & 13,400 & 16,600 \\
Phalacrocorax carbo & 1,400 & 8,700 \\
\hline
\end{tabular}

Table 2. Numbers counted of some species at country-wide surveys in the Baltic archipelagos from Kalmarsund to Väddö.

\begin{tabular}{lcr}
\hline Species & $1971-1974$ & \multicolumn{1}{c}{2004} \\
\hline Anas platyrhynchos & 5,600 & 7,100 \\
Aythya fuligula & 16,100 & 67,200 \\
Bucephala clangula & 3,050 & 23,600 \\
Mergus merganser & 4,100 & 6,100 \\
Cygnus olor & 1,570 & 5,300 \\
\hline
\end{tabular}


from the country-wide surveys as this species is difficult to cover adequately in aerial surveys. Pochard, on the other hand, has a local distribution, mostly concentrated on the Blekinge archipelago. In Goosander, the country-wide survey showed a quite marked increase for the archipelagos, but these areas are not so well represented in the annual indices, which did not show any clear picture.

A more detailed presentation will be given below for three more common species.

\section{Mallard (Anas platyrhynchos)}

The Mallard is a widespread wintering species distributed over the entire southern part of Sweden, both inland and in coastal sites. The country-wide surveys in
2004 showed a total of the wintering population in the open coasts and southern archipelagos between Halland and northern Kalmarsund of 73,400 with a further 7,100 in the east coast archipelagos further north, compared to 28,000 and 5,600, respectively, at the counts in 19711974.

The national midwinter index for the Mallard (Fig. 2A) showed a clear increase over the entire span of midwinter counts, but the series can actually more properly be split into two. For the first years up to the cold winter of 1987 the series of indices can be described as a fluctuation around a more or less steady level, but after 1987 with the onset of a whole series of milder winters, it shows a clearly increasing trend even if individual in-
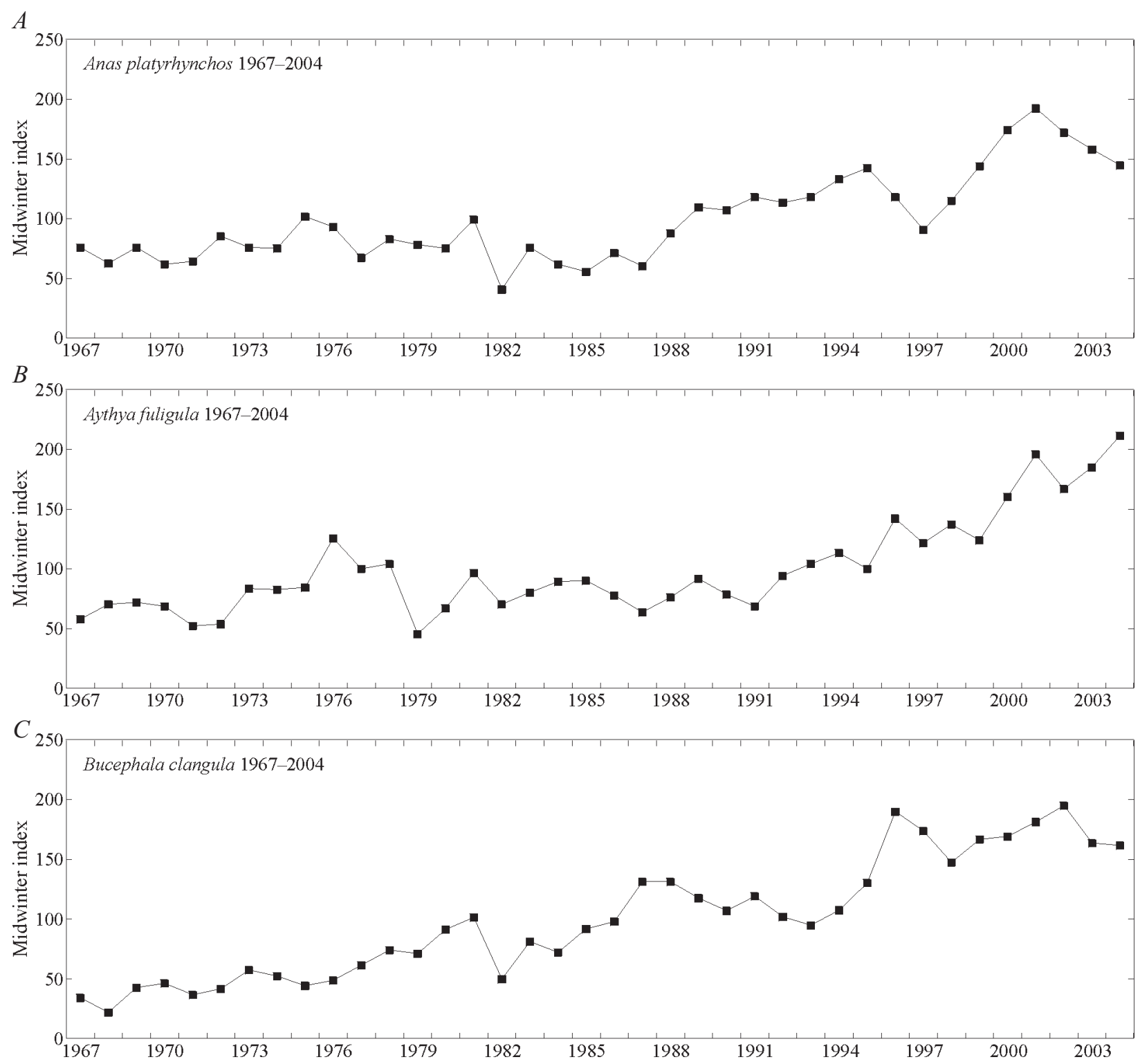

Figure 2. National midwinter indices for the A) Mallard (Anas platyrhynchos), B) Tufted Duck (Aythya fuligula) and C) Goldeneye (Bucephala clangula) in Sweden 1967-2004. 
dex values show marked variations around the trend line. The individual sites, in most cases show a similar picture, with increasing numbers in most areas during the latter part of the counting period (Fig. 3) even if the tendency is less marked in some areas. In the Öresund there are no big differences between the early and later counts with the exception of a number of high counts in the latter part of the period.

\section{Tuffted Duck (Aythya fuligula)}

The Tufted Duck is a typical Baltic coast species in Sweden (especially if the Öresund is also included in the Baltic). Numbers inland in midwinter as well west coast counts are low compared with the totals for the Baltic coast. In January 2004, the Swedish population
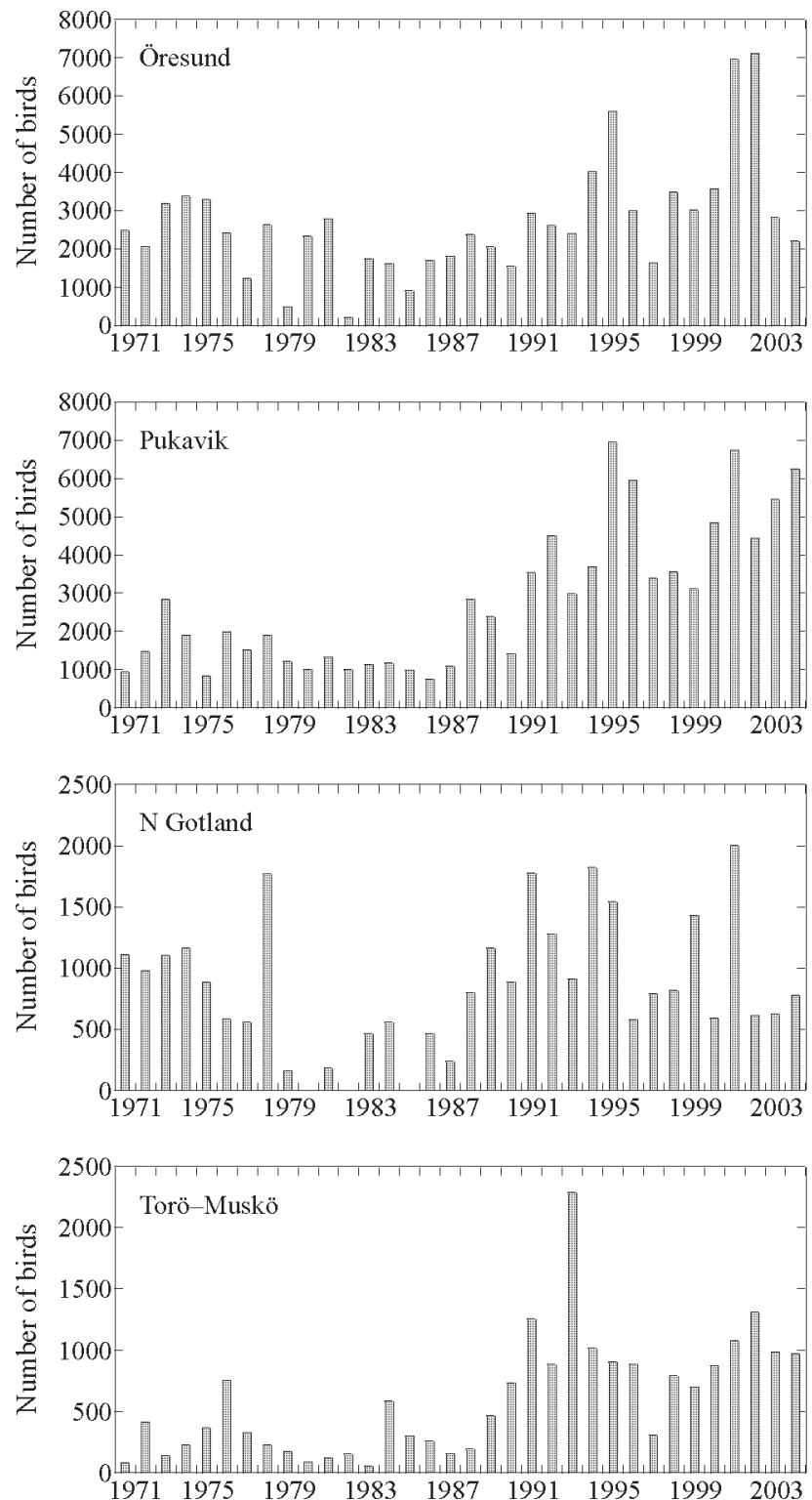

was around 220,000 individuals compared to 69,000 in the early 1970 s.

The national midwinter indices for the Tufted Duck show a marked increase over the long series (Fig. 2B). However, as in the Mallard, the index series can more or less be described as fluctuations around a steady level for the first part followed by a marked increase during the latter period. This marked increase is also reflected in the country-wide surveys (Tables 1,2 ).

Different sites show a more varying picture for the Tufted Duck than for the Mallard (Fig. 4). The annual variation is quite marked, as the Tufted Duck as a diving duck is much influenced by the local ice conditions in the areas. In Scania, the southernmost province of Sweden, the
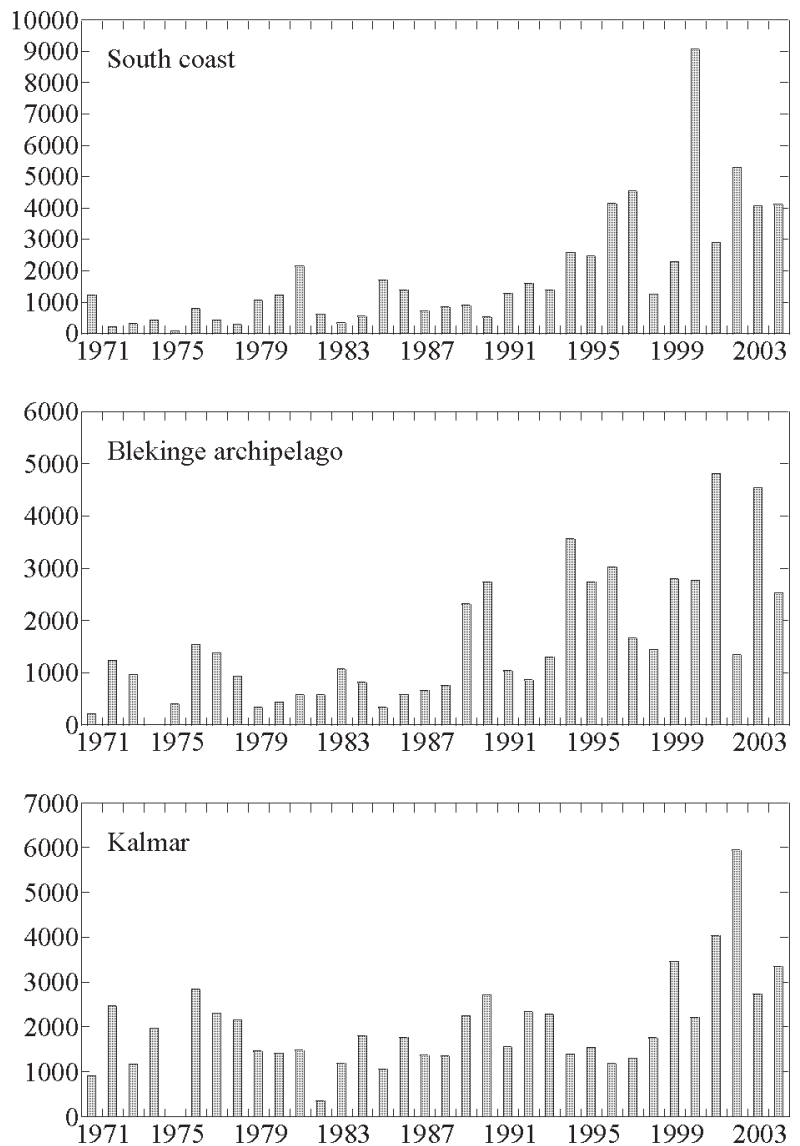

Figure 3. Number of Mallards (Anas platyrhynchos) counted in some areas (Fig. 1) on the Baltic coast of Sweden in 1967-2004. 

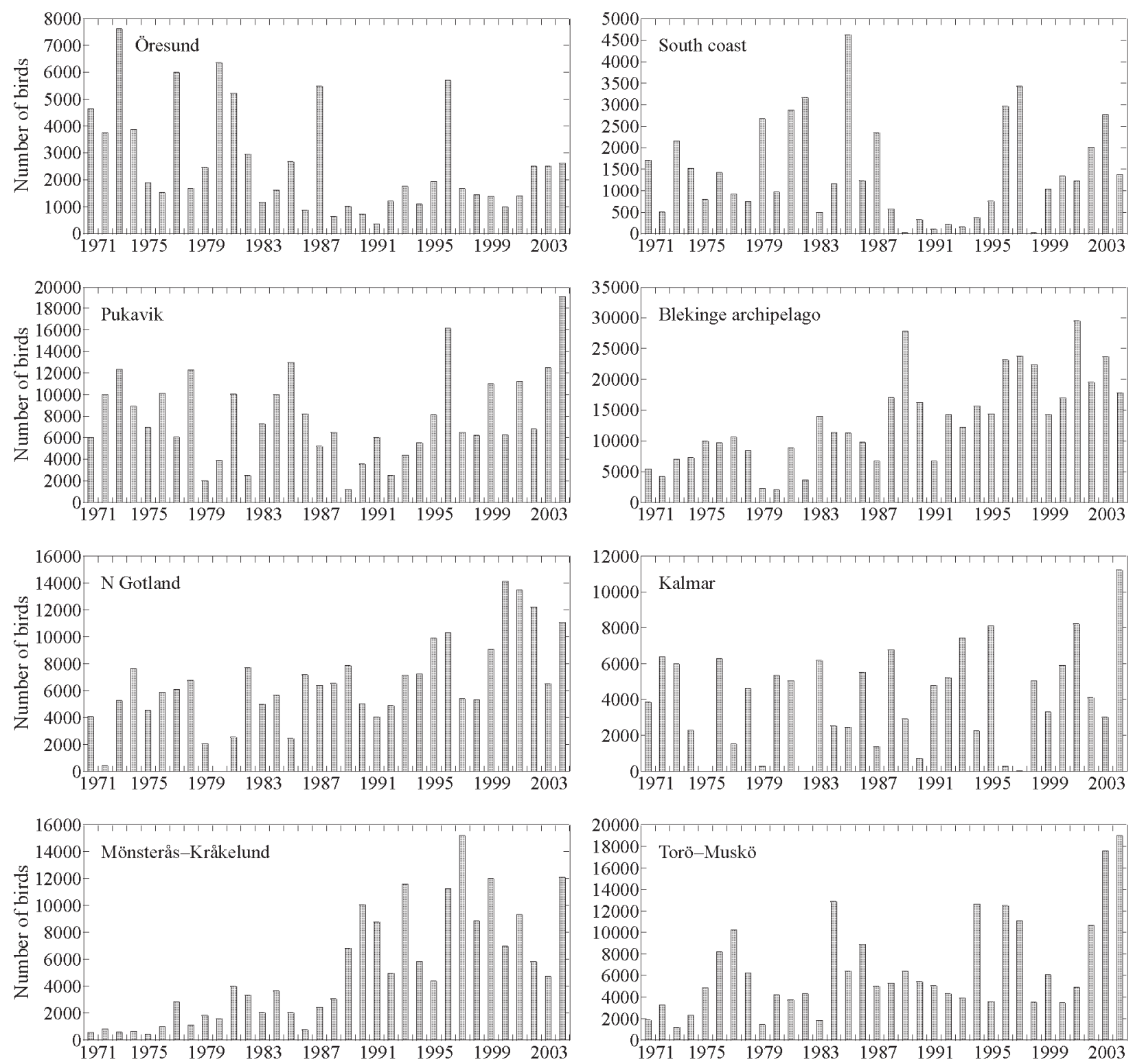

Figure 4. Number of Tufted Ducks (Aythya fuligula) counted in some areas (Fig. 1) on the Baltic coast of Sweden in $1967-2004$.

Öresund area showed a generally decreasing trend in the number of Tufted Ducks, whereas the south coast did not show any clear trends in the number of wintering Tufted Ducks. High counts occurred in years with cold weather before or during the count, when many Tufted Ducks left areas further to the north in the Baltic.

In the province of Blekinge there was a marked increase in the number of Tufted Ducks in the archipelago, which offer excellent Tufted Duck habitats in mild winters, whereas no such tendency was found for the Pukavik area which is more open, and where Tufted Ducks from the archipelagos gather in colder weather. The areas further north in the Baltic all showed increases in the numbers of Tufted Ducks in later years, but there was much variation, to a large extent due to changing icecondition between years.

\section{Goldeneye (Bucephala clangula)}

The Goldeneye is mainly a coastal species in Sweden, but in contrast to the Tufted Duck it is also common on the west coast. The wintering population along the Baltic coasts incl. Kattegatt increased from more than 20,000 in the 1970 s to nearly 56,000 in 2004 .

The national indices for the Goldeneye showed a markedly increasing trend (Fig. 2C). Most regional data sets show increases as in the other two species analysed, but there are some differences (Fig. 5). There was no marked tendency for the Goldeneye counts in two areas of open Baltic coast at the south coast of Scania and on Gotland. 

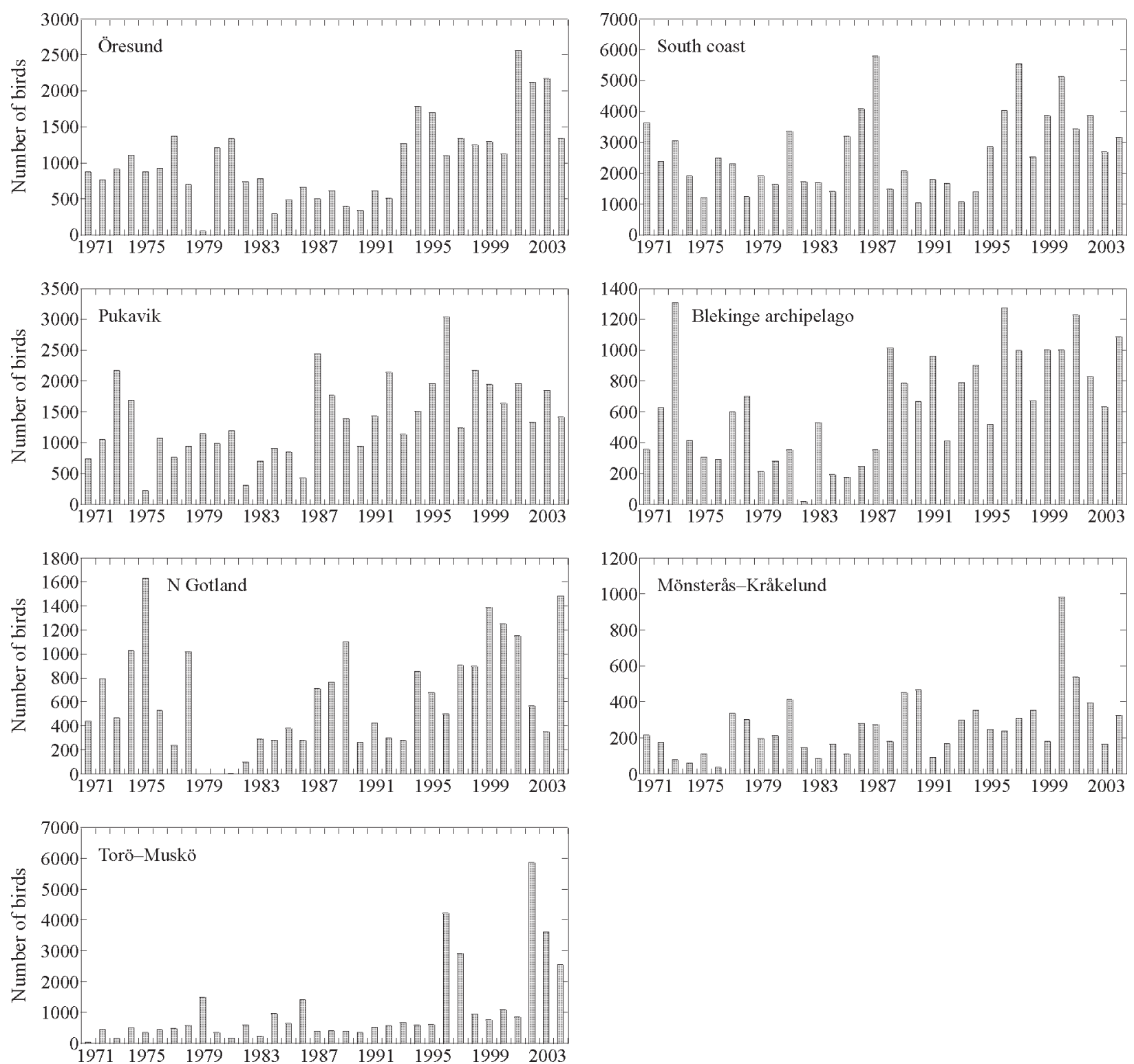

Figure 5. Number of Goldeneyes (Bucephala clangula) counted in some areas (Fig. 1) on the Baltic coast of Sweden in 1967-2004.

On the other hand, a number of wintering Goldeneyes in the Öresund increased.

Upon comparing the development in the annually covered sites and the tendency from the country-wide surveys it is clear that a large part of the increase in the east coast areas fall on archipelago sites that are not so well covered by the annually counted sites.

\section{Discussion}

In the three species analysed on a regional basis in the present contribution, marked increases were noted as was the case also for a number of other wintering wa-

terfowl species in Sweden. A full discussion about the factors behind these changes is out of the scope of this paper, especially as it requires a large scale analysis of data from the International Waterfowl Census that are not yet available. In general the changes in numbers can either reflect true changes in the populations of different species or merely changes in the distribution of different species during winter. For the species discussed here there are indications on cases where the changes reflect genuine changes in the population level, whereas for other species it is more probable that the changes seen in Sweden are reflecting changes in the winter distribution of some species, probably in relation to milder winters in more recent years. 
In the three species analysed in more detail here there are clear indications that the recent set of milder winters can be of importance. All three species have shown marked increases in wintering numbers as had a number of other species not treated in detail in this contribution. Regional changes can also in part be related to changes in winter temperature. Thus significant negative correlations could be established between the residual deviations from total numbers of wintering Tufted Ducks and Goldeneye in Scania, the southernmost province of Sweden, and residual temperature deviations (L. Nilsson, in prep.). No such relations were found for the Mallard. For a full analysis of changes in the distribution of wintering waterfowl in relation to changing winter conditions, comparisons between the results from the midwinter counts from all countries around the Baltic are essential.

There is no indication of a generally increasing trend in the international midwinter indices for the Mallard (Delany et al. 1999), so the increase in the national and regional Swedish indices is most probably an effect of an increasing tendency to stay for the winter during the recent milder winters. In the Tufted Duck, the international indices (Delany et al. 1999), the Baltic/Nordic indices show an increase as the Central European, whereas the North-west European indices show a steady level. For the Goldeneye both the North-west European and the Baltic indices from the IWC indicate an increase.

\section{REFERENCES}

Delany, S., Reyes, C., Hubert, E., Pihl, S., Rees, E., Haanstra, L. and van Strien, A. 1999. Results from the International Waterbird Census in the Western Palearctic and South West Asia 1995 and 1996. Wetlands International Publication 54. Wageningen, The Netherlands.

Nilsson, L. 1972. Habitat selection, food choice, and feeding habits of diving ducks in coastal waters of south Sweden during the non-breeding season. Ornis Scandinavica 3: 55-78.

Nilsson, L. 1975. Midwinter distribution and numbers of
Swedish Anatidae. Ornis Scandinavica 6: 83-107.

Nilsson, L. 1976. Monthly counts as a measure of population changes in some species of Anatidae in south Sweden. Ornis Scandinavica 7: 193-205.

Nilsson, L. 1991. Distribution, population size and longterm changes in population size of wintering waterfowl in Sweden. Ornis Svecica 1: 11-28 (in Swedish with English summary).

\section{ILGALAIKIAI VANDENS PAUKŠČIỤ, ŽIEMOJANČIŲ BALtiJos JŪRoJe TIEs PIETINe ŠvediJA, SKAITLINGUMO IR PASISKIRSTYMO POKYČIAI}

\section{Nilsson}

\section{SANTRAUKA}

Reguliarios žiemojančių vandens paukščių apskaitos vykdomos nuo 1964 m. kaip Tarptautinès vandens paukščių apskaitų programos (IWC) ir Švedijos nacionalinès aplinkos monitoringo programos dalis. Siekiant nustatyti žiemojančių vandens paukščių skaitlingumo pokyčius, apskaitos kasmet tuo pačiu laikotarpiu vykdomos tam parinktose teritorijose. Pilnos apskaitos visoje Švedijoje (iskaitant iš lèktuvų vykdomas apskaitas) buvo atliktos 1971-1974, 1987-1989, 1992-1993 (dalinè) ir 2004 m. Apskaitos laikotarpiu užregistruotos šiųžiemojančių rūšių gausèjimo tendencijos: didžiosios anties, kuoduotosios anties, rudgalvès anties, klykuolès, vidutinio dančiasnapio, gulbès nebylès ir kormorano. Kai kurių rūšiu pagausèjimas atspindi jų populiacijų didejjimą, o kitų rūšių skaičiaus padidejjimas yra susijęs su besikeičiančiomis žiemos sąlygomis, pvz. naujų cyplès žiemaviečių formavimasis Švedijoje. Kuoduotosios anties ir klykuolès skaičius Švedijos pietuose mažèjo, o šiaurinèje pakrantèje - didèjo. Didžiosios anties skaitlingumas padidèjo tik kai kuriose teritorijose.

Received: 7 February 2005 Accepted:17 May 2005 